\title{
Methane emission from wetlands in Taiwan
}

\author{
Tsan-Chang Chang ${ }^{\mathrm{a}, \mathrm{b}}$, Shang-Shyng Yang ${ }^{\mathrm{a}, \mathrm{c}, *}$ \\ ${ }^{a}$ Department of Biochemical Science and Technology, National Taiwan University, Taipei 10617, Taiwan \\ ${ }^{\mathrm{b}}$ Mackay Junior College of Nursing, Taipei 112, Taiwan \\ ${ }^{\mathrm{c}}$ Graduate Institute of Biotechnology, National Pingtung University of Science and Technology, Pingtung 91201, Taiwan
}

Received 27 March 2003; received in revised form 27 June 2003; accepted 3 July 2003

\begin{abstract}
To investigate methane emission from wetlands in Taiwan, soil properties, environmental conditions and methane emission were determined at three wetlands in northern Taiwan from September 1995 to April 1999. Soil pH values ranged from 6.15 to 7.80 . Total organic carbon and total nitrogen contents were high in Kuan-du wetland and Kang-nan lake area, where the soils were sandy loam. In Kang-nan wetland, total organic carbon and total nitrogen contents were low and the soil was clay loam. Soil redox potential of Kuan-du wetland and Kang-nan lake area was lower than that of Kang-nan wetland. Atmospheric methane concentration was 0.8-2.7, 0.7-1.6 and 0.8-1.7 ppm $\left(\mathrm{mg} \mathrm{kg}^{-1}\right)$ in Kang-du wetland, Kang-nan wetland and Kang-nan lake area, respectively. Average methane emission rate was $1.82,0.14$ and $0.23 \mathrm{mg} \mathrm{m}^{-2} \mathrm{~h}^{-1}$ and annual methane emission was about $1.59 \times 10^{-1}, 1.23 \times 10^{-2}$ and $2.02 \times 10^{-2}$ ton ha ${ }^{-1}$, respectively. Annual methane emission from 11,896 ha of nine wetlands is estimated around 340 ton in Taiwan.

(C) 2003 Elsevier Ltd. All rights reserved.
\end{abstract}

Keywords: Methane flux; Wetland; Soil properties; Environmental conditions

\section{Introduction}

Methane is considered as one of the most important greenhouse gases because of its high potential for thermal absorption (Segers, 1998). The increase in atmospheric methane from 0.72 to $1.78 \mathrm{ppmv}$ is estimated to be responsible for about $15 \%$ enhancement in the greenhouse effect (Wang et al., 1996). The major sources are rice paddies, wetlands, sediments, enteric fermentation, animal wastes treatment and landfills under low redox potential conditions and the producers are obligate anaerobes (Yang, 1998; Clair et al., 2002; Hegde et al., 2003; Yang et al., 2003a, b). Methane emission from wetlands is estimated to $110 \mathrm{Tg} \mathrm{gr}^{-1}$,

*Corresponding author. Department of Biochemical Science and Technology, National Taiwan University, Taipei 10617 , Taiwan. Tel.: + 886-2-2362-1519; fax: + 886-2-2367-9827.

E-mail address: ssyang@ntu.edu.tw (S.-S. Yang). and it is one of the largest natural sources of atmospheric methane, accounting for about $21 \%$ of the current global annual methane budget (Watson et al., 1992). Methane production and emission from wetland involved complex physiological processes of plants and microorganisms which were regulated by climatic and environmental factors (Cao et al., 1998).

Recently, it has increased interest in the contribution of wetlands to global methane budget (Nakano et al., 2000; Takeuchi et al., 2003). Natural wetlands were permanently or temporarily waterlogged, so that anaerobic conditions consequently developed for methanogenesis to occur. In order to understand the observed trends and predict the future atmospheric methane concentration, an accurate budget of the sources and sinks of atmospheric methane is required. In this paper, we focus on the seasonal variations of methane emissions from three different wetlands located in 
northern Taiwan and role of environmental factors in regulation of methane emission from these wetlands.

\section{Materials and methods}

\subsection{Sampling location}

Kuan-du wetland $\left(25^{\circ} 07^{\prime} \mathrm{N}, 120^{\circ} 27^{\prime} \mathrm{E}\right.$, about $\left.170 \mathrm{ha}\right)$, Kang-nan wetland $\left(24^{\circ} 45^{\prime} \mathrm{N}, 120^{\circ} 53^{\prime} \mathrm{E}\right.$, about $\left.3000 \mathrm{ha}\right)$ and Kang-nan lake area $\left(24^{\circ} 45^{\prime} \mathrm{N}, 120^{\circ} 53^{\prime} \mathrm{E}\right.$, about 0.2 ha) in the northern Taiwan were selected for investigation. The Kuan-du musk was collected from the crossing place of the Tanswei and Keelung Rivers. The Kang-nan musk was collected from the riverside of Kehya Brook. The sedges that grow in Kuan-du wetland are tufted Phragmites communis and tufted Cyperus malaccensis. The plants that grow in Kang-nan wetland are Kandelia candel. There is a diurnal variation of flood tide and ebb tide twice a day in these wetlands and it takes $12 \mathrm{~h} 24 \mathrm{~min}$ for each tide cycle.

\subsection{Environmental conditions}

Air temperature was higher than soil temperature in summer and it was reverse in winter. The highest light intensity of Kuan-du wetland appeared in August 1996 and ranged from 5894 to $9332 \mu \mathrm{molm}^{-2} \mathrm{~s}^{-1}$, while Kang-nan wetland had the highest light intensity in May 1998 and was between 10805 and $14734 \mu \mathrm{mol} \mathrm{m}{ }^{-2} \mathrm{~s}^{-1}$. The lowest value was in January 1998 and was between 785 and $982 \mu \mathrm{mol} \mathrm{m}^{-2} \mathrm{~s}^{-1}$ and between 687 and $2456 \mu \mathrm{mol} \mathrm{m}^{-2} \mathrm{~s}^{-1}$, respectively. The highest air temperature was $38^{\circ} \mathrm{C}$ and $39^{\circ} \mathrm{C}$ in August 1996 and the lowest one was $13^{\circ} \mathrm{C}$ and $14^{\circ} \mathrm{C}$ in January 1998 in Kuan-du wetland and Kang-nan wetland, respectively. The highest soil temperature was $34^{\circ} \mathrm{C}$ and $33^{\circ} \mathrm{C}$ in August 1996 and the lowest one was $15^{\circ} \mathrm{C}$ and $10^{\circ} \mathrm{C}$ in January 1998 , respectively.

\subsection{Soils}

The properties of Kuan-du wetland soil were sandy loam, pH $6.7 \pm 0.5$, total organic carbon $2.07 \pm 0.04 \%$ (dry weight), total nitrogen $0.18 \pm 0.02 \%, \mathrm{NH}_{4}^{+}-\mathrm{N}$ $13.0 \pm 0.1 \mathrm{mg} \mathrm{kg}^{-1}, \quad \mathrm{NO}_{3}^{-}-\mathrm{N} \quad 4.8 \pm 0.3 \mathrm{mg} \mathrm{kg}^{-1}, \quad \mathrm{CEC}$ $7.12 \pm 0.92 \mathrm{~ms} \mathrm{~cm}^{-1}$ and redox potential (Eh) -425 to $-300 \mathrm{mV}$, while those of Kang-nan wetland soil were clay loam, $\mathrm{pH} 7.2 \pm 0.2$, total organic carbon $1.53 \pm$ $0.19 \%$ (dry weight), total nitrogen $0.15 \pm 0.02 \%$, $\mathrm{NH}_{4}^{+}-\mathrm{N} 20.0 \pm 0.10 \mathrm{mg} \mathrm{kg}^{-1}, \mathrm{NO}_{3}^{-}-\mathrm{N} 3.0 \pm 0.0 \mathrm{mg} \mathrm{kg}^{-1}$, CEC $12.77 \pm 1.98 \mathrm{~ms} \mathrm{~cm}^{-1}$ and $\mathrm{Eh}-180-200 \mathrm{mV}$. Kangnan lake area soil was sandy loam, $\mathrm{pH} 7.2 \pm 0.5$, total organic carbon $2.05 \pm 0.27 \%$ (dry weight), total nitrogen $0.21 \pm 0.05 \%, \quad \mathrm{NH}_{4}^{+}-\mathrm{N} \quad 34.0 \pm 0.1 \mathrm{mg} \mathrm{kg}^{-1}, \mathrm{NO}_{3}^{-}-\mathrm{N}$ $3.0 \pm 0.1 \mathrm{mg} \mathrm{kg}^{-1}$, CEC $7.26 \pm 1.11 \mathrm{~ms} \mathrm{~cm}^{-1}$ and Eh
-400 to $-180 \mathrm{mV}$. Most of soil Eh after ebb was lower than that before flooding.

\subsection{Gas sampling method}

Gas samples were collected using a home-made acrylic chamber (length $40 \mathrm{~cm}$, width $40 \mathrm{~cm}$ and height $65 \mathrm{~cm}$, about 961) that was equipped with an electronic fan, a thermometer and a sampling hole. For methane emission measurement, the acrylic chamber was installed on the surface of wetland soils and four chambers were used in each measurement. Methane emission rate was measured at $0.5 \mathrm{~h}$ intervals for $1.0 \mathrm{~h}$ by examine the changes of methane concentration in the acrylic chamber. Five $\mathrm{ml}$ of the gas sample was injected into a serum bottle that had been flushed with oxygen-free nitrogen gas. The gas sample in the headspace was injected on a Shimadzu 14A gas chromatograph (Shimadzu Co., Japan) with a Porapak Q glass column $(0.26 \mathrm{~mm} \times 2 \mathrm{~m})$ and an FID detector. The column temperature was set at $100^{\circ} \mathrm{C}$, and the injection and detector temperatures were set at $130^{\circ} \mathrm{C}$. Methane concentration was calculated with a standard curve from 0.1 to $1000 \mathrm{mg} \mathrm{kg}^{-1}$ (vol) (Chang and Yang, 1997).

\subsection{Estimation of methane emission}

Methane emission from wetlands was calculated by the experimental data and estimated by the following equation (Rolston, 1986): $F=(V / A)(\Delta C / \Delta t)$, where $F$ is the methane emission rate $\left(\mathrm{mg} \mathrm{m}^{-2} \mathrm{~h}^{-1}\right), V$ is the volume of chamber above soil $\left(\mathrm{m}^{3}\right), A$ is the cross-section of chamber $\left(\mathrm{m}^{2}\right), \Delta C$ is the concentration difference between zero and $t$ times $\left(\mathrm{mg} \mathrm{cm}^{-3}\right)$, and $\Delta t$ is the time duration between two sampling periods $(\mathrm{h})$. Methane emission from wetland soil was calculated from the summation of methane emission in each year for 4-year measurement.

\subsection{Analytical methods}

Total organic carbon was analyzed by the wet oxidation Walkley-Black method, and organic matter content was calculated as $\mathrm{C} \times 1.724$ (Nelson and Sommers, 1982). Total nitrogen was measured by the modified Kjeldahl method (Yang et al., 1991). Light intensity was measured with a Toshiba SPI-5 photometer. Soil pH $(10 \mathrm{~cm}$ depth) or water $\mathrm{pH}$ was directly determined in the wetland or on 1:1 (w/w) soil to water suspension with a $\mathrm{pH}$ meter. Redox potential was measured with a Hanna No. 081-854 potential meter under 5-20 cm depth of topsoil using the Pt electrode for 20-25 min equilibrium with the soil (Yang and Chang, 1997). A thermometerdetermined air, water and soil temperatures. Experiments were carried out to obtain four measurements, and flux data subjected to analysis of variance and Duncan's 
multiple range tests $(p=0.05)$ using the Statistical Analysis System (SAS Institute, 2002).

\section{Results}

\subsection{Methane emission in Kuan-du wetland}

Methane emission is the net result of methane production and methane oxidation. Atmospheric methane concentrations, methane emission rates, total organic carbon, total nitrogen and soil Eh of Kuan-du wetland are given in Fig. 1. Average atmospheric methane concentration was $1.57 \pm 0.13 \mathrm{ppmv}$ with the maximum value $2.62 \mathrm{ppmv}$ before flooding tide in January 1996 and the minimum one $0.82 \mathrm{ppmv}$ before flooding tide in January 1998. Average methane emission rate was $1.82 \mathrm{mg} \mathrm{m}^{-2} \mathrm{~h}^{-1}$, where the maximum value was $5.67 \mathrm{mg} \mathrm{m}^{-2} \mathrm{~h}^{-1}$ after ebb tide in October 1996 with high total organic carbon $(2.89 \%)$, total nitrogen $(0.22 \%)$ and soil temperature $\left(28^{\circ} \mathrm{C}\right)$, and low $\mathrm{Eh}(-376 \mathrm{mV})$ and pressure $(1012.1 \mathrm{hPa})$, while the minimum one was $0.01 \mathrm{mg} \mathrm{m}^{-2} \mathrm{~h}^{-1}$ before flooding tide in March 1996 with low total nitrogen $(0.12 \%)$ and soil temperature $\left(12^{\circ} \mathrm{C}\right)$, and mediate soil $\mathrm{Eh}$ $(-315 \mathrm{mV})$ and pressure $(1018.0 \mathrm{hPa})$.

\subsection{Methane emission in Kang-nan wetland}

Atmospheric methane concentrations, methane emission rates, total organic carbon, total nitrogen and soil Eh of Kang-nan wetland are presented in Fig. 2. Average atmospheric methane concentration was $1.04 \pm 0.19 \mathrm{ppmv}$ with the highest value $1.51 \mathrm{ppmv}$ before flooding tide in October 1995 and the lowest one 0.78 ppmv before flooding tide in January 1996. Average methane emission rate was $0.14 \mathrm{mg} \mathrm{m}^{-2} \mathrm{~h}^{-1}$ and the highest value was $0.17 \mathrm{mg} \mathrm{m}^{-2} \mathrm{~h}^{-1}$ after ebb tide in August 1996 with high total organic carbon (1.67\%), total nitrogen $(0.15 \%)$ and soil temperature $\left(33.5^{\circ} \mathrm{C}\right)$, and low Eh $(-180 \mathrm{mV})$ and pressure $(1000.3 \mathrm{hPa})$, while the lowest one was $0.01 \mathrm{mg} \mathrm{m}^{-2} \mathrm{~h}^{-1}$ before flooding tide in November 1995 with low total organic carbon $(1.45 \%)$, total nitrogen $(0.12 \%)$ and soil temperature $\left(28.5^{\circ} \mathrm{C}\right)$, and high $\mathrm{Eh}(190 \mathrm{mV})$ and pressure (1013.5 hPa).

\subsection{Methane emission in Kang-nan lake area}

For the investigation of anthropogenic contaminations on methane emission rate, Kang-nan lake area with high total organic carbon and near Kang-nan

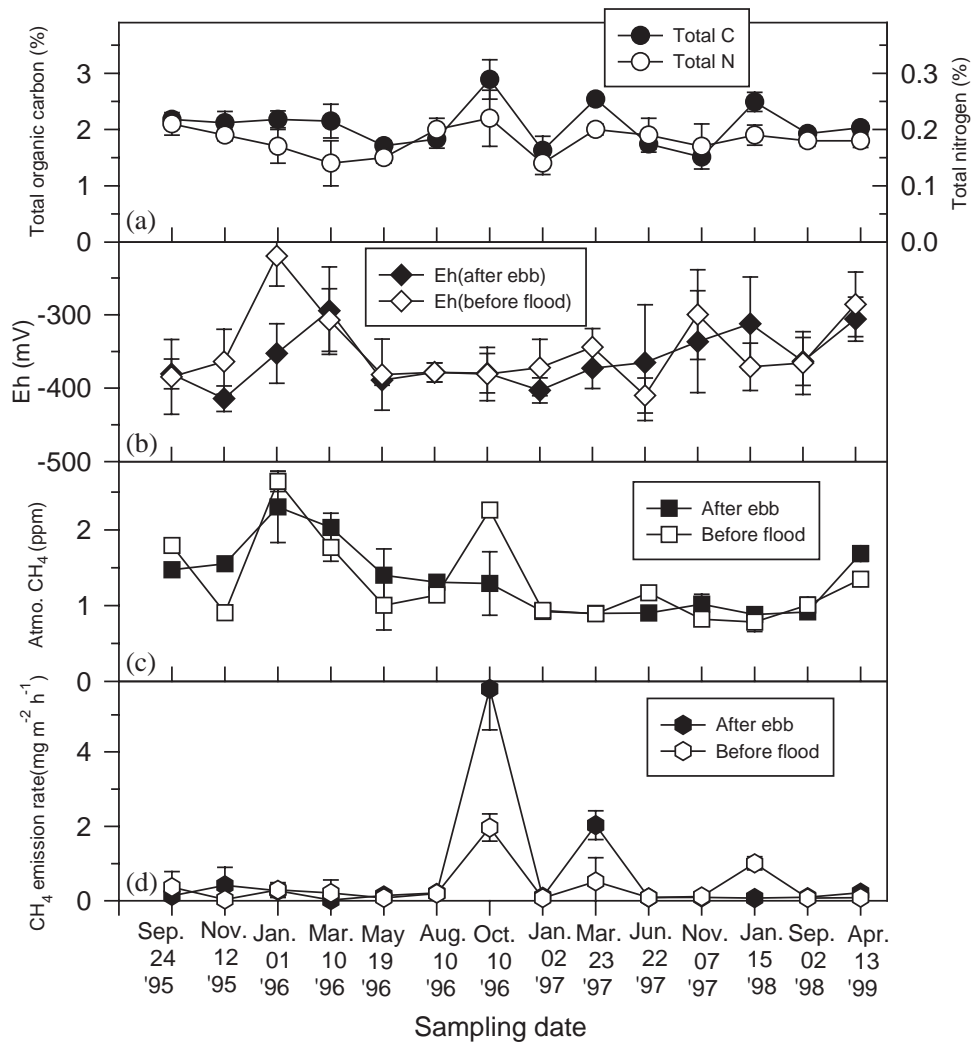

Fig. 1. Soil properties, atmospheric methane and methane emission rate of Kuan-du wetland: (a) total organic carbon and total nitrogen, (b) soil redox potential, (c) atmospheric methane, (d) methane emission rate. 


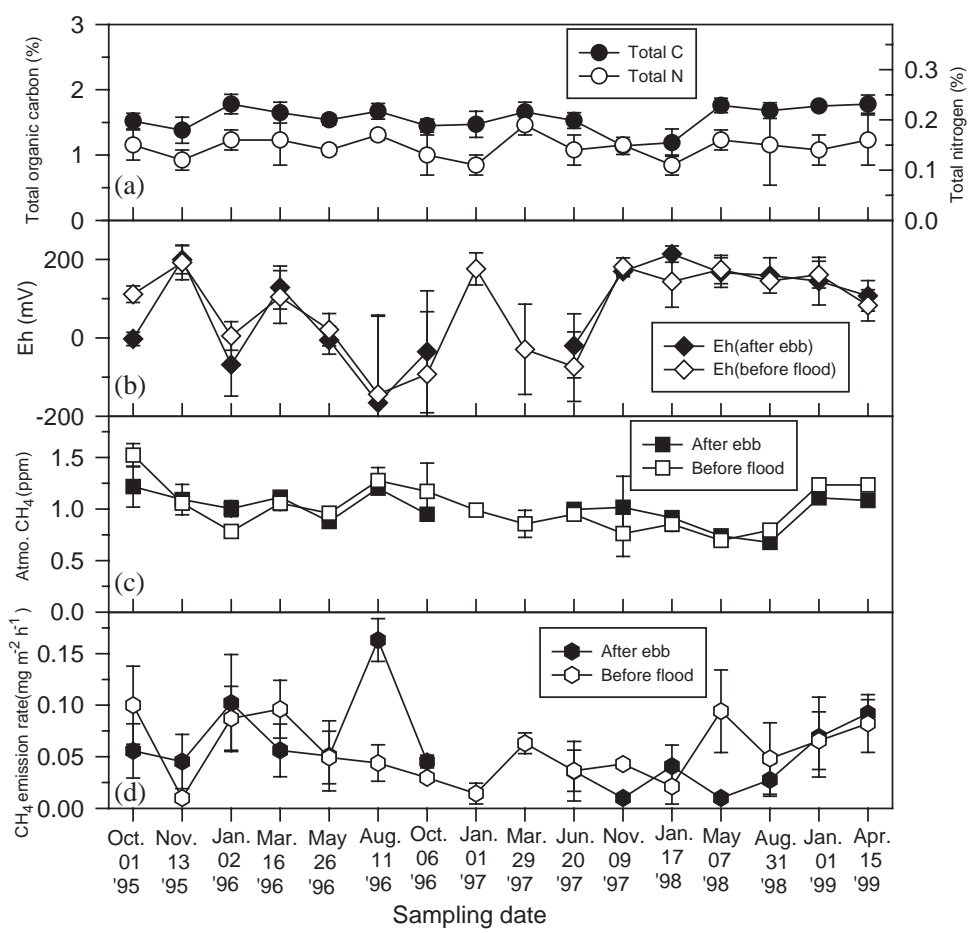

Fig. 2. Soil properties, atmospheric methane and methane emission rate of Kang-nan wetland: (a) total organic carbon and total nitrogen, (b) soil redox potential, (c) atmospheric methane, (d) methane emission rate.

wetland was chosen. The effluents from fish farm are discharged in this area. Average atmospheric methane concentration was $1.05 \pm 0.21 \mathrm{ppmv}$ and the value was very similar with that measured in Kang-nan wetland (Figs. 2 and 3). The average methane emission rate was found to be $0.23 \mathrm{mg} \mathrm{m}^{-2} \mathrm{~h}^{-1}$ and the maximum rate $5.42 \mathrm{mg} \mathrm{m}^{-2} \mathrm{~h}^{-1}$ in January 1998 with high total organic carbon $(2.80 \%)$ and total nitrogen $(0.37 \%)$ and low soil Eh $(-350 \mathrm{mV})$ and pressure $(1008.4 \mathrm{hPa})$, while the minimum rate $0.01 \mathrm{mg} \mathrm{m}^{-2} \mathrm{~h}^{-1}$ in November 1997 with low total organic carbon $(1.66 \%)$ and total nitrogen $(0.17 \%)$ and high soil Eh $(-230 \mathrm{mV})$ and pressure (1017.2 hPa).

\subsection{Seasonal variation of methane emission from wetlands}

Seasonal variations of atmospheric methane concentrations and methane emission rates are demonstrated in Table 1. Atmospheric methane concentrations showed no significant differences among the seasons at three tested wetlands. However, methane emission rates had significant differences. Spring and autumn had high methane emission rates, and summer and winter had low values in Kuan-du wetland and Kang-nan lake area, while methane emission rates had high values in summer and autumn and they had low rates in spring and winter in Kang-nan wetland.

\subsection{Effect of soil properties and environmental conditions on methane emission}

Methane emissions from Kuan-du wetland were higher than those from Kang-nan wetland due to the high total organic carbon and total nitrogen and low soil Eh. Therefore, the correlations between methane emission rates and soil properties or environmental conditions were studied and the results are shown in Table 2. It was found that methane emission rates had high correlation coefficient with total organic carbon $\left(r^{2}=\right.$ $0.38-0.67)$ and total nitrogen $\left(r^{2}=0.29-0.61\right)$, while the values were low in soil Eh $\left(r^{2}=0.01-0.45\right)$, light intensity $\left(r^{2}=0.09-0.43\right)$, soil temperature $\left(r^{2}=\right.$ $0.01-0.23)$, air temperature $\left(r^{2}=0.01-0.18\right)$, chamber temperature $\left(r^{2}=0.01-0.10\right)$ and soil $\mathrm{pH} \quad\left(r^{2}=\right.$ $0.01-0.11)$.

\section{Discussion}

Soil properties are the major factors influencing methane emission in all tested wetlands. Methanogenic bacteria are $\mathrm{pH}$ sensitive and most of them grow over a relatively narrow $\mathrm{pH}$ range of about 6-8. Crozier et al. (1995) reported an optimum $\mathrm{pH}$ of 7.7 for methane emission in coastal wetlands. The tested wetlands had $\mathrm{pH}$ values between 6.15 and 7.80 which are within the 


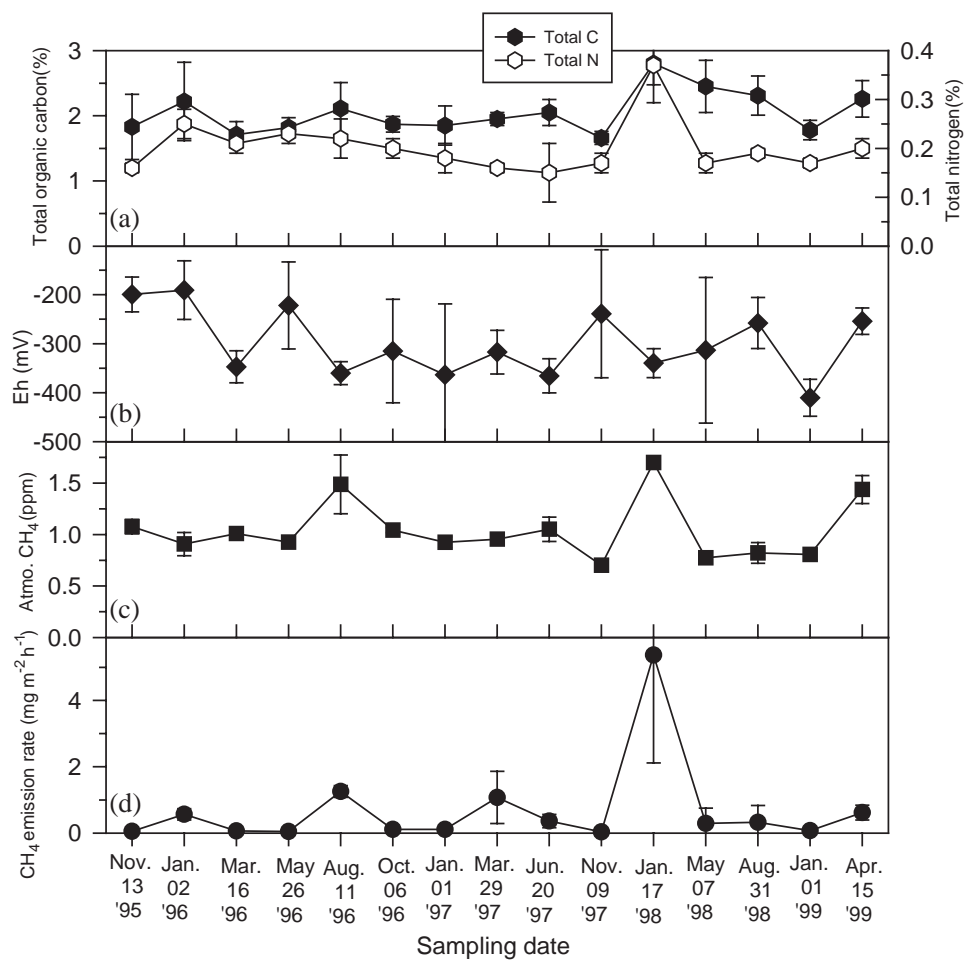

Fig. 3. Soil properties, atmospheric methane and methane emission rate of lake area of Kang-nan wetland: (a) total organic carbon and total nitrogen, (b) soil redox potential, (c) atmospheric methane, (d) methane emission rate.

Table 1

Seasonal variation of atmospheric methane concentration and methane emission rate of wetlands

\begin{tabular}{llll}
\hline Season & $\begin{array}{l}\text { Kuan-du } \\
\text { wetland }\end{array}$ & $\begin{array}{l}\text { Kang-nan } \\
\text { wetland }\end{array}$ & $\begin{array}{l}\text { Kang-nan } \\
\text { lake area }\end{array}$ \\
\hline (a) Atmospheric methane concentration $(\mathrm{ppm})$ & \\
Spring & $1.44 \pm 0.25^{\mathrm{a}}$ & $0.98 \pm 0.07^{\mathrm{a}}$ & $1.05 \pm 0.27^{\mathrm{a}}$ \\
Summer & $1.22 \pm 0.05^{\mathrm{a}}$ & $1.09 \pm 0.03^{\mathrm{a}}$ & $1.01 \pm 0.05^{\mathrm{a}}$ \\
Autumn & $1.40 \pm 0.24^{\mathrm{a}}$ & $0.96 \pm 0.22^{\mathrm{a}}$ & $1.04 \pm 0.06^{\mathrm{a}}$ \\
Winter & $1.20 \pm 0.21^{\mathrm{a}}$ & $1.02 \pm 0.12^{\mathrm{a}}$ & $1.02 \pm 0.05^{\mathrm{a}}$ \\
& & & \\
(b) Methane & emission rate $\left(\mathrm{mg} \mathrm{m}^{-2} \mathrm{~h}^{-1}\right)$ & \\
Spring & $0.51 \pm 0.21^{\mathrm{a}}$ & $0.06 \pm 0.03^{\mathrm{b}}$ & $0.51 \pm 0.09^{\mathrm{a}}$ \\
Summer & $0.18 \pm 0.04^{\mathrm{c}}$ & $0.09 \pm 0.01^{\mathrm{a}}$ & $0.21 \pm 0.11^{\mathrm{b}}$ \\
Autumn & $0.59 \pm 0.14^{\mathrm{a}}$ & $0.09 \pm 0.03^{\mathrm{a}}$ & $0.44 \pm 0.23^{\mathrm{a}}$ \\
Winter & $0.25 \pm 0.11^{\mathrm{b}}$ & $0.04 \pm 0.01^{\mathrm{c}}$ & $0.06 \pm 0.05^{\mathrm{c}}$ \\
\hline
\end{tabular}

Mean \pm S.D. $(n=14)$. Means in the same row that did not share the same alphabetic superscript were significantly different at $5 \%$ level according to Duncan's multiple range tests.

$\mathrm{pH}$ range for optimum growth of methanogens. Therefore, the effect of soil $\mathrm{pH}$ on methane emission in tested wetlands was low $\left(r^{2}=0.01-0.11\right)$. About $80 \%$ of methane is produced biologically under low Eh conditions by obligate anaerobes. Kuan-du wetland and
Kang-nan lake area soils were sandy loam with low Eh (below $-250 \mathrm{mV}$ ) and hence favored methane production. In contrast, Kang-nan wetland was clay loam with high Eh (between -180 and $200 \mathrm{mV}$ ) and so was unfavorable methane production. Soil Eh below $-150 \mathrm{mV}$ was considered to be critical for the initiation of methane production (Wang et al., 1996; Yang and Chang, 1998). Soil Eh ranged from -180 to $200 \mathrm{mV}$ in Kang-nan wetland, and the effect of Eh on methane emission was high after ebb $\left(r^{2}=0.45\right)$; while Eh was between -425 and $-300 \mathrm{mV}$ in Kuan-du wetland and between -400 and $-180 \mathrm{mV}$ in Kang-nan lake area, and the effect of Eh on methane emission was low in both tested areas $\left(r^{2}=0.01-0.04\right)$.

Kuan-du wetland is located at the crossing place of the Tanswei and Keelung Rivers and has heavy pollution in the downstream area with high methane emission; while Kang-nan wetland is located in the Kehya Brook and has light pollution in the downstream area with low methane emission. Yagi and Minami (1990) reported that methane production increased with the amount of soil organic matter content. Total organic carbon had the highest correlation coefficient with methane emission $\left(r^{2}=0.38-0.67\right)$, followed by total nitrogen $\left(r^{2}=0.32-0.61\right)$ and $\mathrm{C} / \mathrm{N}$ ratio $\left(r^{2}=\right.$ $0.11-0.35$ ). Rask et al. (2002) indicated that methane fluxes were high in the string and deep bay and had 
Table 2

Correlations between methane emission rate $(Y)$ and soil properties or environmental conditions

\begin{tabular}{|c|c|c|c|}
\hline Wetland & Properties or conditions $(X)$ & Equation & $r^{2}$ \\
\hline \multirow[t]{2}{*}{ Kuan-du wetland } & \multirow[t]{4}{*}{ Total organic carbon } & $Y=2.86 X-5.22($ after ebb $)$ & 0.52 \\
\hline & & $Y=1.13 X-1.97$ (before flood) & 0.67 \\
\hline \multirow[t]{2}{*}{ Kang-nan wetland } & & $Y=0.13 X-0.13$ (after ebb) & 0.38 \\
\hline & & $Y=0.10 X-0.09$ (before flood) & 0.42 \\
\hline Kang-nan lake area & & $Y=3.13 X-5.72($ after ebb $)$ & 0.54 \\
\hline \multirow[t]{2}{*}{ Kuan-du wetland } & \multirow[t]{4}{*}{ Total nitrogen } & $Y=34.79 X-5.57($ after ebb) & 0.32 \\
\hline & & $Y=12.25 X-1.83$ (before flood) & 0.34 \\
\hline \multirow[t]{2}{*}{ Kang-nan wetland } & & $Y=1.18 X-0.11($ after ebb $)$ & 0.29 \\
\hline & & $Y=0.93 X-0.08$ (before flood) & 0.45 \\
\hline Kang-nan lake area & & $Y=20.28 X-3.57($ after ebb $)$ & 0.61 \\
\hline \multirow[t]{2}{*}{ Kuan-du wetland } & \multirow[t]{4}{*}{$\mathrm{C} / \mathrm{N}$ ratio } & $Y=0.23 X-5.00($ after ebb $)$ & 0.23 \\
\hline & & $Y=0.22 X-2.07$ (before flood) & 0.35 \\
\hline \multirow[t]{2}{*}{ Kang-nan wetland } & & $Y=0.01 X-0.06($ after ebb $)$ & 0.20 \\
\hline & & $Y=0.01 X-0.05$ (before flood) & 0.19 \\
\hline Kang-nan lake area & & $Y=0.22 X+2.98($ after ebb $)$ & 0.11 \\
\hline \multirow[t]{2}{*}{ Kuan-du wetland } & \multirow[t]{4}{*}{ Soil redox potential } & $Y=-0.01 X-2.48($ after ebb) & 0.04 \\
\hline & & $Y=-0.002 X-0.269$ (before flood) & 0.03 \\
\hline \multirow[t]{2}{*}{ Kang-nan wetland } & & $Y=-0.0002 X-0.0736($ after ebb $)$ & 0.45 \\
\hline & & $Y=0.01 X-0.05$ (before flood) & 0.01 \\
\hline Kang-nan lake area & & $Y=-0.004 X-0.441($ after ebb) & 0.04 \\
\hline \multirow[t]{2}{*}{ Kuan-du wetland } & \multirow[t]{4}{*}{ Soil pH } & $Y=0.40 X-2.12($ after ebb $)$ & 0.01 \\
\hline & & $Y=-0.18 X+1.66$ (before flood) & 0.02 \\
\hline \multirow[t]{2}{*}{ Kang-nan wetland } & & $Y=0.01 X+0.04($ after ebb $)$ & 0.01 \\
\hline & & $Y=0.04 X-0.26$ (before flood) & 0.11 \\
\hline Kang-nan lake area & & $Y=0.70 X-4.29($ after ebb $)$ & 0.03 \\
\hline \multirow[t]{2}{*}{ Kuan-du wetland } & \multirow[t]{4}{*}{ Air temperature } & $Y=0.02 X+0.22$ (after ebb) & 0.01 \\
\hline & & $Y=-0.02 X+0.81$ (before flood) & 0.06 \\
\hline \multirow[t]{2}{*}{ Kang-nan wetland } & & $Y=0.01 X+0.04($ after ebb $)$ & 0.02 \\
\hline & & $Y=0.01 X+0.05$ (before flood) & 0.05 \\
\hline Kang-nan lake area & & $Y=0.03 X-0.44($ after ebb $)$ & 0.18 \\
\hline \multirow[t]{2}{*}{ Kuan-du wetland } & \multirow[t]{4}{*}{ Chamber temperature } & $Y=-2.43 X+0.74($ after ebb $)$ & 0.01 \\
\hline & & $Y=-0.02 X+0.81$ (before flood) & 0.06 \\
\hline \multirow[t]{2}{*}{ Kang-nan wetland } & & $Y=0.0014 X+0.0121($ after ebb) & 0.06 \\
\hline & & $Y=0.0006 X+0.00359$ (before flood) & 0.02 \\
\hline Kang-nan lake area & & $Y=0.02 X-0.22($ after ebb $)$ & 0.10 \\
\hline \multirow[t]{2}{*}{ Kuan-du wetland } & \multirow[t]{4}{*}{ Soil temperature } & $Y=0.08 X-0.99$ (after ebb) & 0.06 \\
\hline & & $Y=3.10 X+0.29$ (before flood) & 0.01 \\
\hline \multirow{2}{*}{ Kang-nan wetland } & & $Y=0.0013 X+0.0232($ after ebb) & 0.04 \\
\hline & & $Y=0.00205 X+0.00208$ (before flood) & 0.15 \\
\hline Kang-nan lake area & & $Y=0.03 X-4.29($ after ebb $)$ & 0.23 \\
\hline \multirow[t]{2}{*}{ Kuan-du wetland } & Light intensity & $Y=-5.66 \times 10^{-6} X+0.49($ after ebb $)$ & 0.09 \\
\hline & & $Y=5.74 \times 10^{-6} X+0.20$ (before flood) & 0.12 \\
\hline Kang-nan wetland & & $Y=3.5 \times 10^{-3} X+3.47($ after ebb $)$ & 0.09 \\
\hline & & $Y=5.8 \times 10^{-3} X-2.24 \times 10^{-2}($ before flood $)$ & 0.43 \\
\hline
\end{tabular}

positive correlations with $\mathrm{C} / \mathrm{N}$ ratio, but there was no relationship between methane flux and $\mathrm{C} / \mathrm{N}$ ratio in the shallow bay. Nitrogen mineralization was not likely directly related to methane production.

Methane emission was high in summer and low in winter. Methane production is enhanced with increasing temperature in wetlands (Freeman et al., 2002). Methane emission had a linear correlation with soil temperature between $15^{\circ} \mathrm{C}$ and $30^{\circ} \mathrm{C}$ and the emission was undetectable when the soil temperature was below $10^{\circ} \mathrm{C}$ (Rask et al., 2002). The soil temperature effect on methane emission was high, and then followed by chamber and air temperatures. Light might affect the oxygen distribution and penetration in the water-air interface, and enhance methane oxidation (Khalil, 1995). King (1990) indicated that illumination could possibly induce the growth and photosynthesis of algae and the oxidation of methane, but reduces the emission of methane. In contrast, the correlation between methane emission and light intensity was low after ebb 
$\left(r^{2}=0.09\right)$, and the value was mediate before flooding $\left(r^{2}=0.12-0.43\right)$. The difference might be due to the high temperature and low moisture content of tested wetlands before flooding.

Atmospheric methane concentrations at the period after ebb were higher than those at the period before flooding due to the low Eh at submerged anaerobic conditions for methanogen growth and methane production (Sass et al., 1994; Singh et al., 2000). Methane emission rate of Kuan-du wetland $\left(1.82 \mathrm{mg} \mathrm{m}^{-2} \mathrm{~h}^{-1}\right)$ was the highest among the tested areas, while Kang-nan wetland was the lowest $\left(0.14 \mathrm{mg} \mathrm{m}^{-2} \mathrm{~h}^{-1}\right)$. These values were higher than that was measured by Wang et al. (1997) in the shallow seashore areas of southern Taiwan $\left(0.02 \mathrm{mg} \mathrm{m}^{-2} \mathrm{~h}^{-1}\right)$, Wang and Shieh (1997) in Tadu wetland in central Taiwan $\left(0.051 \mathrm{mg} \mathrm{m}^{-2} \mathrm{~h}^{-1}\right)$ and Tzuwen wetland in southern Taiwan $\left(0.005 \mathrm{mg} \mathrm{m}^{-2} \mathrm{~h}^{-1}\right)$, and Velichko et al. (1998) in tundra, forest-tundra, and bogs within the boreal zone in northern Eurasia $\left(0.46-0.63 \mathrm{mg} \mathrm{m}^{-2} \mathrm{~h}^{-1}\right)$. It was same level as that was determined by Aselmann and Crutzen (1989) in the assessment methane emission from global wetlands $\left(1.66 \mathrm{mg} \mathrm{m}^{-2} \mathrm{~h}^{-1}\right)$, Cao et al. (1998) in the northern natural wetlands $\left(1.67 \mathrm{mg} \mathrm{m}^{-2} \mathrm{~h}^{-1}\right)$, and $\mathrm{Na}$ kano et al. (2000) in the waterlogged site at Tiksi (Arctic Siberia) near the mouth of Lena River $\left(1.93 \mathrm{mg} \mathrm{m}^{-2} \mathrm{~h}^{-1}\right)$. However, methane emission from Kuan-du wetland was less than that was proposed by Shurpali et al. (1993) in Minnesota peatland (1.25$6.67 \mathrm{mg} \mathrm{m}^{-2} \mathrm{~h}^{-1}$ ), Boeckx and van Cleemput (1997) in global wetlands $\left(2.08-4.15 \mathrm{mg} \mathrm{m}^{-2} \mathrm{~h}^{-1}\right)$, Cao et al. (1998) in the temperate and tropical natural wetlands (6.26-8.13 $\mathrm{mg} \mathrm{m}^{-2} \mathrm{~h}^{-1}$ ), Nakano et al. (2000) in the waterlogged site at Chersky on the lower Kolyma River $\left(11.71 \mathrm{mg} \mathrm{m}^{-2} \mathrm{~h}^{-1}\right)$, Singh et al. (2000) in the vegetated surface of five natural wetlands in north India (7.30$67.72 \mathrm{mg} \mathrm{m}^{-2} \mathrm{~h}^{-1}$ ), and Takeuchi et al. (2003) in the open bog of west Siberian wetland $\left(9.71 \pm 13.59 \mathrm{mg} \mathrm{m}^{-2} \mathrm{~h}^{-1}\right)$. Shurpali et al. (1993) showed that episodic methane emission had 2-3 times larger than gradual (nonepisodic) pattern. Episodic emissions are associated with significant drops in atmospheric pressure and decline in water table. The effect of atmospheric pressure on methane emission from wetland was less significant in Taiwan. Therefore, these differences of methane emission from wetland might be due to the locations, soil properties and environmental conditions.

Seasonal variation of methane emission rate was significantly different among the tested wetlands in Taiwan. Spring and autumn had high values in Kuan-du wetland and Kang-nan lake area, while there was a high rate in summer and autumn in Kang-nan wetland. Harriss et al. (1985) indicated that methane emission rate was between 8.33 and $25.0 \mathrm{mg} \mathrm{m}^{-2} \mathrm{~h}^{-1}$ in summer and autumn of the wetland near Minnesota, and Roulet et al. (1992) reported that methane emission rate was only $0.13-0.54 \mathrm{mg} \mathrm{m}^{-2} \mathrm{~h}^{-1}$ in winter season, and Singh et al. (2000) showed that methane emission rate from the vegetated surface of Gomti River was maximum in summer season $\left(67.72 \mathrm{mg} \mathrm{m}^{-2} \mathrm{~h}^{-1}\right)$, followed by rainy season $\left(28.83 \mathrm{mg} \mathrm{m}^{-2} \mathrm{~h}^{-1}\right)$, and had the least in winter season $\left(14.92 \mathrm{mg} \mathrm{m}^{-2} \mathrm{~h}^{-1}\right)$.

In this study, annual methane emission from Kuan-du wetland, Kang-nan wetland and Kang-nan lake area with 4-year data was $1.59 \times 10^{-1}, 1.23 \times 10^{-2}$ and $2.02 \times 10^{-2}$ ton ha $^{-1}$, respectively. Average methane emission was $6.38 \times 10^{-2}$ ton $\mathrm{ha}^{-1}$. Annual methane emission from 11,896 ha of nine wetlands in Taiwan is estimated at around 340 ton.

\section{Acknowledgements}

The authors thank Professors C.H. Chou, H.C. Lin, Y.S. Wang, C.M. Lai and C.H. Chen for their helpful comments, Dr. U. Hegde and Mr. I.C. Chen for technical assistances, and the National Science Council of the Republic of China for financial support (NSC 872621-P002-021, NSC 88-EPA-Z-002-014 and NSC 89EPA-Z-002-003).

\section{References}

Aselmann, I., Crutzen, P., 1989. Global distribution of natural freshwater wetlands and rice paddies their net primary productivity, seasonability and possible methane emissions. Journal of Atmospheric Chemistry 8, 307-358.

Boeckx, P., van Cleemput, O., 1997. Methane emission from a freshwater wetland in Belgium. Soil Science Society of America Journal 61, 1250-1256.

Cao, M., Gregson, K., Marshall, S., 1998. Global methane emission from wetlands and its sensitivity to climate change. Atmospheric Environment 32, 3293-3299.

Chang, H.L., Yang, S.S., 1997. Measurement of methane emission from soil. Journal of Chinese Agricultural Chemical Society 35, 475-484.

Clair, T.A., Arp, P., Moore, T.R., Dalva, M., Meng, F.R., 2002. Gaseous carbon dioxide and methane, as well as dissolved organic carbon losses from a small temperature wetland under a changing climate. Environmental Pollution 116, S143-S148.

Crozier, C.R., Devai, I., DeLaune, R.D., 1995. Methane and reduced sulfur gas production by fresh and dried wetland soil. Soil Science Society of America Journal 59, 277-284.

Freeman, C., Nevison, G.B., Kang, H., Hughes, S., Reynolds, B., Hudson, J.A., 2002. Contrasted effects of simulated drought on the production and oxidation of methane in a mid-Wales wetland. Soil Biology and Biochemistry 34, 61-67.

Harriss, R.C., Gorham, E., Sebacher, D.J., Bartlett, K.B., Flebbe, R.A., 1985. Methane flux from northern peatlands. Nature 315, 652-654. 
Hegde, U., Chang, T.C., Yang, S.S., 2003. Methane and carbon dioxide emission from shan-chu-ku landfill site in northern taiwan. Chemosphere 52, 1275-1285.

Khalil, M.A.K., 1995. Greenhouse gases in the earth's atmosphere. Encyclopedia of Environmental Biology 2, 251-265.

King, G.M., 1990. Regulation by light of methane emission from a wetland. Nature 345, 513-515.

Nakano, T., Kuniyoshi, S., Fukuda, M., 2000. Temporal variation in methane emission from tundra wetlands in a permafrost area, northeastern Siberia. Atmospheric Environment 34, 1205-1213.

Nelson, D.W., Sommers, L.E., 1982. Total carbon, organic carbon and organic matter. In: Page, A.L. (Ed.), Methods of Soil Analysis. Part 2: Chemical and Microbiological Properties, 2nd Edition. American Society of Agronomy, Madison, Wisconsin, pp. 539-580.

Rask, H., Schoenan, J., Anderson, D., 2002. Factors influencing methane flux from a boreal forest wetland in Saskatchewan, Canada. Soil Biology and Biochemistry 34, 435-443.

Rolston, D.E., 1986. Gas flux. In: Klute, A. (Ed.), Methods of Soil Analysis, 2nd Edition, Monograph No. 9. American Society of Agronomy and Soil Science Society of America, Wisconsin, pp. 1103-1119.

Roulet, N.T., Ash, R., Moore, T.R., 1992. Low boreal wetlands as a source of atmospheric methane. Journal of Geophysical Research 97, 3739-3749.

SAS Institute., 2002. SAS User's Guide Statistics. SAS Institute Inc., Gary, North Carolina.

Sass, R.L., Fisher, F.M., Lewis, S.T., 1994. Methane emissions from rice fields: effect of soil properties. Global Biogeochemistry Cycles 8, 135-140.

Segers, R., 1998. Methane production and methane consumption: a review of processes underlying wetland methane fluxes. Biogeochemistry 41, 23-51.

Shurpali, N.J., Verma, S.B., Clement, R.J., 1993. Seasonal distribution of methane flux in a Minnesota peatland measured by eddy correlation. Journal of Geophysical Research 98, 20649-20655.

Singh, S.N., Kulshreshtha, K., Agnihotri, S., 2000. Seasonal dynamics of methane emission from wetlands. Chemosphere: Global Change Science 2, 39-46.

Takeuchi, W., Tamura, M., Yasuoka, Y., 2003. Estimation of methane emission from west Siberian wetland by scaling technique between NOAA AVHRR and SPOT HRV. Remote Sensing of Environment 85, 21-29.

Velichko, A.A., Kremenetski, C.V., Borisova, O.K., Zelikson, E.M., Nechaev, V.P., Faure, H., 1998. Estimates of methane emission during the last 125,000 years in northern Eurasia. Global and Planetary Change 16-17, 159-180.

Wang, Y.P., Shieh, S.W., 1997. The emission and the environmental conditions of paddy soil, wetland, dryland, upland soil and forest soil in the central and southern Taiwan area. In: Lu, S.C., Liu, C.M., Yang, S.S. (Eds.), Change of Atmospheric Environments in Taiwan Area. Global Change Research Center and Department of Agricultural Chemistry, National Taiwan University. Taipei, Taiwan, pp. 99-121.

Wang, Z.P., Zeng, D., Patrick Jr., W.H., 1996. Methane emission from natural wetlands. Environment Monitoring Assessment 42, 142-161.

Wang, S.L., Chen, A.C.T., Chang, C.M., 1997. Methane flux of the near seashore watershed in Taiwan. In: Lu, S.C., Liu, C.M., Yang, S.S. (Eds.), Change of Atmospheric Environments in Taiwan Area. Global Change Research Center and Department of Agricultural Chemistry, National Taiwan University. Taipei, Taiwan, pp. 143-154.

Watson, R.T., Neira Filho, L.G., Sanhueza, E., Janetos, A., 1992. Sources and sinks. In: Houghton, J.J., Callander, J.T., Vamey, S.K. (Eds.), The Supplementary Report to the IPCC Scientific Assessment. Cambridge University Press, Cambridge, pp. 24-46.

Yagi, K., Minami, K., 1990. Effect of organic matter application on methane emission from some Japanese paddy fields. Soil Science and Plant Nutrition 36, 599-610.

Yang, S.S., 1998. Methane production of river and lake sediments in Taiwan. Environmental Geochemistry and Health 18, 245-250.

Yang, S.S., Chang, E.H., 1997. Effect of fertilizer application on methane production in paddy soils of Taiwan. Biology and Fertility of Soils 25, 245-251.

Yang, S.S., Chang, H.L., 1998. Effect of environmental conditions on methane production and emission from paddy soil. Agriculture Ecosystems and Environment 69, 69-80.

Yang, S.S., Chang, H.L., Wei, C.B., Lin, H.C., 1991. Reduce waste production in the Kjeldahl methods. Journal of the Biomass Energy Society of China 10, 147-155.

Yang, S.S., Liu, C.M., Lai, C.M., Liu, Y.L., 2003a. Estimation of methane and nitrous oxide emission from paddy fields and uplands in taiwan during 1990-2000. Chemosphere: 52, 1295-1305.

Yang, S.S., Liu, C.M., Liu, Y.L., 2003b. Estimation of methane and nitrous oxide emission from animal feeding sector in Taiwan during 1990-2000. Chemospere in press. 